\begin{tabular}{|c|c|}
\hline \multicolumn{2}{|r|}{ About the Journal } \\
\hline Journal DOI & https://doi.org/10.21659/rupkatha \\
\hline Journal Home & www.rupkatha.com $\oslash$ \\
\hline Indexed by & Scopus $\triangle$ Web of Science: Emerging Sources Citation Index (ESCI) \\
\hline Journal Metrics & CiteScore 2020: 0.2 | SJR 2020: 0.162 | SNIP 2020: 0.193 | JCI 2020: 0.50 \\
\hline \multicolumn{2}{|r|}{ About the Issue } \\
\hline Themed issue & $\begin{array}{l}\text { Volume 4, number 1, } 2022 \text { (January-March) | Contemporary East and } \\
\text { Southeast Asian Literary and Cultural Studies }\end{array}$ \\
\hline Guest Editors & Dr Jeremy de Chavez $\oslash \&$ Dr Zhang Yue, University of Macau, China \\
\hline Issue DOI & https://doi.org/10.21659/rupkatha.v14n1 \\
\hline TOC & https://rupkatha.com/v14n1.php \\
\hline Peer Review & Under the responsibility of the Guest Editors \\
\hline \multicolumn{2}{|r|}{ About the Article } \\
\hline Title & $\begin{array}{l}\text { Revisiting theatre of the minoritarian in neoliberalism: The Embodied } \\
\text { Memories in Denise Uyehara's and Dan Kwong's Auto-performances }\end{array}$ \\
\hline Author/s & Io Chun KONG $\otimes$ \\
\hline Affiliation & General Education Department, City University of Macau, Macau \\
\hline Author ID & https://orcid.org/0000-0001-6845-7486 \\
\hline Funding & No funding received. Published free of any charge. \\
\hline Article DOI & https://doi.org/10.21659/rupkatha.v14n1.10 Pages: 1-12 \\
\hline Abstract & https://rupkatha.com/v14n110 \\
\hline Full-text PDF & https://rupkatha.com/V14/n1/v14n110.pdf \\
\hline \multirow[t]{3}{*}{ Article History } & Abstract received: 27 Feb 2021 | Complete article received: 30 May 2021 \\
\hline & Revised article received: 12 Aug 2021 | Accepted: 15 Aug 2021 \\
\hline & First Published: 05 February 2022 \\
\hline Article Impact & Check Dynamic Impact \\
\hline Copyright & Aesthetics Media Services $\searrow$ \\
\hline Licensing & Creative Commons Attribution Non-Commercial 4.0 \\
\hline
\end{tabular}

This Open Access article is published under a Creative Commons Attribution Non-Commercial 4.0 International License (http://creativecommons.org/licenses/by-nc/4.0/), which permits non-commercial re-use, distribution, and reproduction in any medium, provided the original work is properly cited. For citation use the DOI. For commercial re-use, please contact editor@rupkatha.com. 
1 Rupkatha Journal, Vol. 14, No. 1, 2022

Research Article

\title{
Revisiting theatre of the minoritarian in neoliberalism: The Embodied Memories in Denise Uyehara's and Dan Kwong's Auto-performances
}

\author{
Io Chun KONG
}

General Education Department, City University of Macau, Macau.

\begin{abstract}
In a neoliberal multicultural landscape, minoritarian artists tend to, deploying various forms of self-media or virtual platforms, create their artistic spaces for their identitarian performances. While self-media has been more and more entrepreneurially dominant, the aura of theatrical performance of the self seems to be now obsolete. Moreover, in view of neoliberalism as an increasing hegemony that has insidiously marginalized theaters of minoritarian performances (such as the New WORLD theater) in the past decade in the U.S., "minoritarian subjects" (to borrow José Esteban Muñoz's term) are experiencing a predicament in which they are becoming more and more visually contingent owing to the neoliberal representational violence. With an urge of reviving such distant aura, this paper revisits the solo performances of Denise Uyehara and Dan Kwong staged in the Highway Performance Space, a generative site of what Meiling Cheng calls the "heterolocus". By exploring auto-performance as a minoritarian genre, the paper examines what Diana Taylor calls the "embodied memories" in the works of Uyehara and Kwong, and further argues that these performances should not be simply understood as an individual aesthetic and political expression, but also be rendered as a powerful epistemological repertoire to perform cultural politics for the communal Asian American theater.
\end{abstract}

Keywords: Neoliberalism, Asian American Theatre, Autoperformance, Embodied Memory, Heterolocus.

\section{Introduction}

With the popularization of what Schwartz and Halegoua call the "spatial selfi" performed via social media and virtual platforms, minoritarian artists tend to create their artistic spaces digitally for their identitarian performances. While self-media has been more and more entrepreneurially dominant, the aura of theatrical performance such as solo performance, together with the impact of COVID-19 pandemic, seems to have become materially distant and obsolete. Moreover, in view of neoliberalism as a naturalizing hegemony that has been insidiously marginalizing theatres of the minoritarian/colors such as the New World Theater in the past decade in the U.S., "minoritarian subjects", referred as the "citizen-subjects debased within the majoritarian public sphere" due to the antagonisms within the social such as race, class, and sex (Muñoz, 2009, p. 56), are experiencing a predicament of "racial contingency", a critical condition I have termed elsewhere that these minoritarian subjects have been becoming visually contingent under the rhetoric of neoliberal multiculturalism. Other than identifying the critical predicament in which 
representations of minoritarian subjects have been visually evasive onstage, "racial contingency" is also theorized as a critical frame to explore the asymmetrical power dynamics problematically adhered with the representational violence of neoliberal multiculturalism (Kong, 2021, p. 16). Therefore, while expressions of arts and humanities have been increasingly digitalized, embodied performances, in a neoliberally saturated context, have been marginalized. Though multiculturalism, under neoliberalism, has been privileged in what Jodi Melamed (2011) terms "a form of racial capitalism portray[ing] an ethic of multiculturalism [as] the spirit of neoliberalism" (p. 42), the ideology is yet easily sugarcoated by the rhetoric of post-racialism and colorblindness. Therefore, in view of the neoliberal context in which multiculturalism has been appropriated as a (post-racial capitalist) hegemony, the US multicultural landscape deserves a critical re-evaluation to inquire the problematic dynamics of neoliberal multiculturalism as a means of incorporating difference without fully attending to asymmetrical dimensions of racialized power. In this case, I particularly address to the critical urge of such racial contingent condition in which revisiting of the minoritarian theatre is necessary and should be deemed as both a strategic and political gesture for reviving the aura of embodied performance.

Undoubtedly, there have been substantial scholarships regarding Asian American cultural and literary works such as novels, poetry, movies, and theatre, but few aspects were paid to solo performance as a theatrical genre particularly embodied by the minoritarian Asian American artists. Whereas Asian American Theater has always been examined as dramatic literature (Josephine Lee, 1997; Karen Shimakawa, 2002; Esther K. Lee, 2006), Asian American (auto)performance, being scrutinized as a part of the discursive performance studies, is yet to be invested. Therefore, it is worth contemplating, with scant critical attention on Asian American solo performance, whether revisiting to the solo performance of the minoritarian would allow us to gain a more critical perspective to rethink and reimagine their culture politics? And further, whether such turn would delimit our critical perspective, as global audience, to reapproach these solo performances (regarded as epistemological repertoire) by making relations of their cohesive and collective cultural politics rather than simply rendering them as individual aesthetic expressions? With these questions, the article will turn to two minoritarian Asian American artists - Denise Uyehara and Dan Kwong - and their autoperformances once staged in 1990s. In this way, the analyses and critiques in this article aim to contribute to the existing scholarship of Asian American theater by proposing a tactic of revisiting to the always neglected site of autoperformance which has been increasingly evaded in a neoliberal context. Also informed by Diana Taylor's performance theory of archive and repertoire, this paper explores the embodied memories of the two artists' works by revisiting to in the site of autoperformance reminiscently staged at the Highways Performance Space. In doing so, the paper argues that these minoritarian solo performances should be understood as archival and epistemological repertoires in which the embodied memories (as rendered by the two sexualized and racialized bodies) enable a more comprehensive perspective to experience the performative link between the individual aesthetic and collective cultural politics of Asian American theater. 


\section{Self-performance/Atuoperformance, Embodied Memory, and Heterolocus}

Before delving into the two solo artists, I would like to foreground several key concepts that are crucial to make theoretical connections between the artists and the way in which their works are staged epistemologically and cultural politically. First of all, auto-performance or selfperformance, as Robert Vorlicky notes, is "an artist-actor's live performance of material drawn from her or his life" - autobiography as the primary material (Vorlicky, 2004, p. 2). By virtue of the genre's inexpensive production costs and appealing (albeit often fraught) relationship with identity politics in the 1990s, autoperformnace (in all its fictional and non-fictional manifestations) has remained a theatrical form that not only cuts across differences of race, class, sex, and education, but also serves as "a necessary outlet for expressing that narratives of their culture the stories of family, traditions, dreams, and "otherness" as experienced inside America's borders" (Vorlicky, 2004, p. 2). While autoperformance has remained an attractive theatrical form for minority artists (LGBTQ as well as the color), the genre, as Daniel Bacalzo (2004) argues, can be regarded "modern technology of the self" that potentially interrogates "the relationship between the art that this work produces and the societal context with which it interacts" (p. 43). Drawing from both Vorlicky and Bacalzo, I particularly value autoperformance's role of serving as the outlet of performing minority subjectivities by elaborating the relationship between those performances and the artists' own lives to larger social, political, and historical concerns. In this way, I propose to scrutinize this aspect through the theoretical lens of performance generatively informed by Diana Taylor.

In The Archive and the Repertoire: Performing Cultural Memory in the Americas, Diana Taylor (2003) tells us that performance, on the one level, constitutes "the object/process of analysis"; on the other, it also constitutes the "methodological lens" that enables analyses of events as performance such as civic obedience, resistance, citizenship, gender, ethnicity, and sexual identity performed daily in the public sphere (p. 3). Whereas performance, as Taylor notes, can function as an epistemology in which "embodied practice offers a way of knowing" (p. 3), performance can also be functioning as "vital acts of transfer, transmitting social knowledge, memory, and a sense of identity through reiterated or what Richard Schechner calls twice-behaved behavior" (p. 2-3).

In addition, Taylor introduces the concepts of archive and repertoire which are instrumental in the process of scrutinizing the autoperformances of Uyehara and Kwong. While "archive" generally refers as supposedly enduring materials such as texts, documents, buildings, and bones, "repertoire" is seen as "embodied practice/knowledge (i.e., spoken language, dance, sports, ritual)" that are "ephemeral" (p. 19). As suggested by Taylor, repertoire enacts embodied memory (namely performances, gestures, orality, movement, dance, singing), but it also requires "presence" - people participate in the production and reproduction of knowledge by "being there, being a part of the transmission" (p. 20). In other words, "embodied memory", via presence or ephemerality, is enacted by repertoire, etymologically a treasury or an inventory, that allows for individual agency. A true performance/repertoire, as argued by both Taylor and Peggy Phelan, then cannot be saved, recorded, documented, or otherwise participate in the circulation of representations of representation. Performance's being, like the ontology of subjectivity, becomes itself through disappearance" (p. 5). If repertoire (when enacting embodied memory) needs to be 
mediated as a process of selection, memorization/internalization, and transmission, these embodied acts (always present) become a constant site of againness that "reconstitute themselves, transmitting communal memories, histories, and values from one group/generation to the next" (Taylor, 2003, p. 21)Asian American autopeformance, if seen as repertoire or embodied acts, would generate, record, and transmit knowledge that circulate between generations as well as the personal (self) to the social (nexus). But in apprehending Asian American performance as repertoire of transferring knowledge, I argue the necessity of theatrical liveliness (i.e., ephemerality) not be dismissed along with the concept of spatiality. Nodding to other theorists of performance studies, I also advocate the importance of theatrical space that is critical to differentiate a live performance from a recorded video show. In this case, Meiling Cheng's "heterolocus" is helpful in comprehending the nuanced difference of theatrical ephemerality. Drawing from Foucault's theorization of "heterotopia" - a conception of real existing like "countersites" or "other spaces", Cheng (2001) reminisces the Highways Performance Space by framing it as "heterolocus, a locus for otherness" (Cheng, 2001, p. 431). She accentuates such heterolocus as a theater of, for, and about otherness, "recuperates from the anonymity that prevails two indispensable bases of live performance: the actor and the performing site" (p. 430). By interpreting the locus as "a dynamic conglomerate of human intentionality, cultural function, and a site of action", Cheng argues that the ideal of a heterolocus can be activated during the course of delving into those principles and practices (p. 431). Indeed, Cheng's essay renders two points deemed crucial to revisiting the autoperformances of two Asian American artists - First, while she differentiates heterotopia from what she calls "heterolocus", she points out that a disembodied virtual space operating within a website may be called a heterotopia, but not a heterolocus; second, if a video of a performance is not quite a performance (as suggested by Taylor and Phelan), the significance of understanding live performance as practices bringing together what "we have historically been kept as discrete, supposedly free-standing, ontological and epistemological discourses" (Taylor, 2003, p. 4) is underlined here to embrace performance as an embodied act that (artistically, culturally, and epistemologically) reveals culture's deepest, truest, and most individual character. Whereas autoperformance is valued of its outlet in performing the Asian American minoritarian subjectivities, I propose that a theoretical application of Taylor's "embodied memories, archive, and repertoire" together with the spatial deployment of Cheng's "heterolocus" will be a significant and generative gesture to reapproach autoperformance via the necessity of revisiting.

\section{The Necessity of Revisiting}

Undoubtedly, Cheng's reminisce on Highways as a "heterolocus" once manifested the democratic ideal of multiculturalism by celebrating the performances of othernessi. But such multicultural ideal, under neoliberal violence, has been degenerated a "porous linguistic vessel absorb[ing] all meanings, keeping none" (p. 346). So in confronting with the status quo asymmetrical structure in which racial contingency is rendered a predicament, I propose that revisiting to the theater of these minoritarian autoperformances is indeed a significant performative act that not only does it reflect on the engenderment of cultural politics, but also revives the aura of theatrical performance 
that illuminates the very embodied act of transferring knowledge across personal self and social nexus. On the one hand, through revisiting to the autoperformances of Denise Uyehara and Dan Kwong, I suggest that their embodied acts engender the cultural politics of what José Esteban Muñoz calls "minoritarian subjects". On the other, these autoperformances, while seen as archival repertoire in a heterolocus, are politically performative due to the very embodied acts of body and memory. If, as Muñoz (2009) suggests, queer futurity requires "cruising" the notion of the future in the present as a gesture to "summon a refunctioned notion of utopia in the service of subaltern politics" (p. 49), the act of cruising is ideally extended, I elaborate further, to the past in which revisiting to those minoritarian autoperformances, in Jean-François Lyotard 's postmodern/post-identity fashion ${ }^{i i i}$, would enable us to account aspects of identitarian thinking, and persist such thinking as our affective investments, means of knowledge production and transference as well as modes of ethico-political engagement and imagination.

\section{Performing Body and Memory: The Embodied Memories of Denise Uyehara and Dan Kwong}

In Asian American theater, I have argued in elsewhere that body and memory are inextricably and interdependently rendered as poetics of diaspora in performance. And autoperforming these two aspects is critical to revisiting the history of racialized subjects (Kong, 2020, p. 2). Here, likewise, the inextricable relationship between body and memory can be seen as, in Taylor terms, "embodied memory" that enables a performative link between the individual aesthetic and collective cultural politics of Asian American theater. Drawing on Beauvoir and Merleau-Ponty, Judith Butler (1988) understands body in terms of "an active process of embodying certain cultural and historical possibilities, a complicated process of appropriation which any phenomenological theory of embodiment needs to describe" (p. 521). If body, as Butler suggests, is a materiality that bears cultural meanings, the manner of this bearing is fundamentally dramatic in a way that the body is "a continual and incessant materializing of possibilities" (p. 521). The body, in other words, is a historical situation as well as a manner of doing, dramatizing, and reproducing a historical situation. To acknowledge the idea that embodiment manifests what Butler (1988) calls "a set of strategies", race, like gender, can be as well considered as "corporeal style", "an act" that is both "intentional and performative" (p. 523). Also, as Josephine Lee suggests (1997), the physical body is at the center of the conceptual fuzziness surrounding the terms of ethnicity and race (p. 189), the body's "corporeal schemaiv" is the interdependent agency while performing one's personal memories into the conscious existence of public history. And theatre, functioning what Meiling Cheng calls a "heterolocus", is the generative site to perform "otherness" of the minoritarian subjects.

If racial body is inscribed with social and historical meanings, the physical body onstage is somehow readily to perform the memories that are not simply personal but also collective. Though autoperformance is always, if not only, about telling one's story with the presence of one's own body, the performance is yet conveying a more profound and significant message, in a larger context, to the social nexus, namely performing social relations with other collectivities (i.e., racial, ethnic, gendered groups). Whereas Highway Performance Space, as Cheng (2001) suggests, is "a home-site for otherness, heterogeneity, and profound longing for an affective community", it 
benefits autoperformance by helping the artists render themselves as the (minoritarian) "other" being named as "multicultural," "ethnic," "feminist," "queer, "poor," "old," "handicap," or "foreign," - through his/her articulation into the host country (p. 448). With the provision of such heterolocus, Denise Uyehara's works, as Yuko Kurashashi (2002) observes, "spoke to audience of all kinds: queer, straight, women, men of all racial backgrounds" (p. 334). Deploying theater, Uyehara's autoperformances produce hetero-sites in which her body, situated in a network of (marginalized) memories, turns to be the center of a map as well as the agent to critique the asymmetrical dynamics of multiculturalism.

Born in California, Denise Uyehara is Japanese American brought up by parents who are both scientists. But instead of pursuing science, Uyehara is committed to pursuing comparative literature, creative writing, and performance. Acclaimed as an interdisciplinary artist, she performs globally including London, Tokyo, Vancouver, Helsinki, China, and across the U.S. Among her autoperformances, Big Head and Maps of City and Body perform a collective cultural politics through archival embodied memories. According to Uyehara (2003), while memory is the key in telling of a tale as well as stories unfold in different art forms, performance, among others, is "visceral" that combines simultaneous elements involving what she describes the "live body in motion over an extended period of time" (Uyehara, 2003, p. 10).

While Big Head, as Uyehara intends, is "an interdisciplinary piece that explores the parallel between the incarceration of Japanese American and those perceived as 'the enemy' - namely Arab and Muslim Americans" (Uyehara, 2003, p. 11), Maps of City and Body takes a "look at collaborations and public art investigations" in which she has participated in over the years. To conceptualize a map as an idealistic self-making that exists in one's body and memory, Uyehara's autoperformances also feature the process of self-performing as a way of subjectivating oneself through embodied memories. As Ether K. Lee suggests (2003), the physical presence of Asian American autoperformers functions as "a statement of its own" and thus delivers a sense of authenticity and realness of their bodies and personal histories (p. 303). By deploying the body in her shows, Uyehara's corporeality signifies what Kim calls a "borderless identity", embracing her existence in the grand history of humanity (p. 303). With this approach of "borderless identity", Uyehara embodies other people's lives and memories so as to build potential coalitions with a shared space and experience simultaneously.

Big Head (2003), as Uyehara conceives, is constituted by a collective sense of small heads filled with "voices from the past and the voices of now" (p. 58). The performance is meant to make empathetic parallels between the historical mistreatment of the Japanese Americans (WWII) and those of Arab American "enemy" in the post-911 political arena. Began by recalling a suspicious arson/incident on $4^{\text {th }}$ July, the performance draws the audience's concern by linking the arson with a racist retaliation - namely, the racial body should be punished. By accentuating her racialized body onstage, Uyehara embodies memories/histories in archival fragmentations. One of these fragmented memories includes an archive titled "The Fourth Grade Book Report" in which the "history of the pledge of allegiance" is put into question in a hetero- public space. While pronouncing "I pledge allegiance to my flag and the Republic for which it stands," her speech act is fraught with identity politics that interrogates what does it mean to be "one nation, indivisible, 
with liberty and justice for all" (p. 28). Her embodied act is extended further when she gestures her palm facing over heart to stretching out like a "Nazi asking for a handout" - to indict, on behalf of her Japanese American great-grandparents, the paradoxical meaning upon the "pledge of allegiance while in the Japanese American Internment camps" (p. 29). By referring to her racialized body as a performative approach of "corporeal schema", Uyehara points to her family archive and delves into Mr. Sumida's incarceration in Arkansas in 1942, a factual case of racial abjection. The historical archive then is used to enact an empathetic understanding and connection with those Muslim Americans who have been, likewise, racialized in the post-911 socio-political landscape. And such racial empathy is delivered, with a reflective juxtaposition, by impersonating Edina Lekovic, a Muslim woman who is abused by a Japanese man at UCLA. To permutate a different perspective between the two minoritarian subjects, Uyehara indicts the fragility of multiculturalism by reframing it as "sort of a joke in our time" (p. 37). On one hand, she does not simply question multiculturalism in terms of a hypocritical promise in the post-911 era, but also implies that critical awareness of those historical racialization (i.e., the Internment lesson) has been somehow obliviated in vain.

Though it is a solo performance, Uyehara is critically aware that the narratives and embodied memories are not simply personal but collective. In the scene of "Vigil", she stages a collective narrative as a performative act and counter-memory to politicize a communal alliance for the Asian Americans:

She moves to stage left and holds the paper in the light of the projector until it catches video footage of an evening candlelight vigil. The silent footage shows a gathering of Arab Americans, Japanese Americans, and Muslims, all holding candles, faces from the very old and the young holding tiny, flickering lights. An amplified guitar plays quietly in the background as various voices from the community speak. (Uyehara, 2003, p. 39)

As its title suggests, Big Head attempts to show a bigger and more inclusive concept to approach and comprehend humanities. To confront with the anti-Asian sentiment, Uyehara seems to know better that a communal alliance is yet to be deployed. But instead of deploying violence as a retaliative means, she approaches it as a reflective notion to see and cohere people. Though posting the obituary of an Asian grocer murdered in San Gabriel, the performer's intention does not aim to infiltrate racist violence; instead, it asks the audience to think through whether it is "just a random act of violence or a hate crime?" (p. 39). Whereas the Japanese American used to change their names to stay away from racism in the post-WII, the Arab American in post-9-11 similarly, are thinking of changing their names for the sake of "being humiliated and the target of racism" (p. 42). And with such identity alteration, the play shows us the fact that history is repeating its nightmarish déjà vu that, Uyehara points out, "over 2000 legal citizens held, secretly deported, and even marked as enemy combatants stripped from their civil rights" (p. 46). To particularly embody this racist violence, Uyehara also projects, with an installation of an animated clay figure being attacked and torn apart repeatedly, a symbolic performance called "ghostly simulacrum of a hate crime" that marks what she calls a three-dimensional violence. Staging embodied memories in a heterolous, Big Head does not simply speak Uyehara's (individual) "borderless identity", but also takes us further to contemplate, through what Erika Fischer-Lichte (1997) calls a "historically 
determined body ${ }^{\mathrm{v}}$, the question - "what does it take to hate a body? What does it hate to take a body?" (p. 50).

If Uyehara's theatrical deployment of her body, as Esther K. Lee (2003) suggests, is a "way of redefining the notion of authenticity" (p. 302) in the context of Asian American history and culture, then the artist's corporeality, as mediated in Dan Kwong' autobiographical self, is also crucial in the process of making relations between the personal (self) and the social (nexus). Known as a veteran performance artist, writer, teacher as well as a master storyteller, Dan Kwong has been creating a new form of solo performance characterized as "autobiographical in content and multimedia in style" (E. K. Lee, 2003, p. 300). In responding to what is his performance philosophy, Kwong asserts that "telling one's story on one's own terms is an act of self-empowerment and validation, as an individual and as a member of a group" (Kwong, 1995, p. 3). To Asian American theater, Kwong's contribution goes beyond his own performances by devoting himself in coaching and inspiring other artists to pursue their autobiographical solo performance as their career. For the same reason, his personal (autobiographical) stories have been used as the primary materials to both subjectivating selfhood as well as making relations with the social nexus. And this making relation is performed by body and memory. As Peggy Phelan (1993) remarks:

Performance art's most radical and innovative work often involves a thrillingly difficult investigation of autobiography. By rejuvenating the possible ways of presenting and representing the self, performance art has changed the notion of theatrical presence and widened the methods by and through which the self can be narrated, parodied, held in contempt, and/or make to be the source of revelatory vision and thought. (Phelan, 1993, p. 28)

From Phelan's view of autobiographical work, we come to understand that the notion of "theatrical presence" is unique to live performance and should be bound with discussions of actor training and audience reception. Through mediation of one's autobiographical self, the artist's presence seems to be amplified by creating an allusion of a one-on-one relationship with their audience. In other words, if autobiography can create an immediacy to the work that is grounded in the personal experience of the live body to be seen on stage, it presents the illusion of authenticity by producing a certain kind of truth. Referring to Foucault's "truth games" in terms of a "set of rules by which truth is produced", Daniel Bacalzo (2004) also sees the production of truth within autobiographical performance that functions as "a contemporary technology of the self that intervenes in existing discourses around representation" (p. 43). Similarly, I also see Kwong's autoperformance (or autobiographical performance) in terms of a "practice/technology of the self" which is a way for the author/performer, via one's own body and memory, not to simply examine his life and actions, but also achieve self-knowledge and transfer (by making relations) such knowledge to the social nexus.

As an American of Chinese and Japanese descent, most of Kwong's works explore sociopolitical issues of Asian American identity such as the model-minority myth, Asian American racialization, and Asian American masculinities etc. Similar to Uyehara's, Kwong's autoperformances were mostly produced in Highways Performance Space where those (self) 
performances are not simply remarked as "an artistic dialect spoken in the heterolocus, but also seen as the paragon vehicle for practicing multiculturalism" back then. (Cheng, 2001, p. 448)

In his anthology From Inner Worlds to Outer Space, Kwong stages two highly autobiographical shows: Monkhood in 3 Easy Lesson (1993) and Correspondence of Dangerous Enemy Alien (1995) - the former interrogates stereotypes of Asian American manhood, whereas the latter historicizes Asian American racialization by incorporating the realities of dislocation, incarceration, and diaspora. In Monkhood, for example, Kwong does not celebrate an American ideal, but an "American shame $\mathrm{v}^{\mathrm{vi}}$ that had to be changed. In his monologue, he indicts that:

I'll probably have to endure some feelings of shame and humiliation and his exquisite Asian body of mine - primarily in regard to secondary sexual characteristics as defined by northern European standards...As well as having to deal with an ugly history of sexless, dehumanizing stereotypes of Asian men, propagated by racist attitudes in popular culture and institutions (Kwong, 2004, p. 84).

Such "American shame", according to Robert F. Sayre, can be productive in relation to the kind of cultural work such as that Monkhood enacts. But instead of embracing such "shame" as a racial melancholia, Kwong's monologue does not simply assert his belief, as an Asian male subject, "to overcome any racist emasculation as an Asian man in this country and contribute" (p. 84), but also enacts an interrogation by questioning why such American ideal is so necessarily constructed upon white heteronormativity. To understand Kwong's embodied acts from Eve Kosofsky Sedwick's "queer performativity - a strategy for the production of meaning and being in relation to the affect of shame" (Sedgwick, 1993, p. 11), we may deconstruct the naturalized white heteronormativity by thinking through Monkhood as a counter political act, namely, to dramatize it through his performance practice that is experienced on a personal level thus giving impact in the formation and articulation of one's own concepts of identity.

Moreover, to render American shame more productively, one of the scenes in Monkhood is to question the truth regarding the nature of sexual relations between men and women by recalling Kwong's own adolescent experience of browsing porn magazines. In the scene, Kwong quotes Xaviera Hollander's comments (also known as "The Happy Hooker" - a columnist who naturally gave the most reliable sources and advice on sexual matters in Playboy and Penthouse) that "the only men I find unsatisfying as lovers are Oriental men [because] their penises are generally too small to provide the necessary friction to get me off" (Kwong, 2004, p. 96). But rather than taking it as a racial shame, Kwong renders this "subject of male organ size" with a tactical humor speaking directly towards the audience that "I was a virgin at the time. I pulled out a ruler. And I became very concerned' (Kwong, 2004a, p. 96). For Kwong, the conflation between the Oriental manhood and lack of "self-esteem, confidence, and performance" as well as sexual impotence is only a stereotypical construction. He questions the equation between manhood and penis size by problematizing that the vain desire of performing a "penis enlargement" is simply a blind follow in the "direction of our society in its attitudes regarding sex, beauty, and the human body" (p. 97). To queer such misconception, Kwong mocks the white heteronormative craving on "penile enlargement" by showcasing various cartoon drawings of penises onstage (including the ones swollen like a water balloon, rippling with bodybuilder muscles, shark-fin-like protrusion one side, and grumpy old man's face on shaft). Gesturing to those images with his Asian body, Kwong 
optimizes the theatrical effect to politically and mockingly discourse - "it matters less the size of your wok than the meal you cook with it" (p. 98). After all, Kwong's body politics is affirmed by his power of performance: in words, sound, light, costume, and choreography to convey action, character and temporarily. The convergence of these performative elements, as Robert Vorlicky (2004) notes, "frees Kwong to release his body amid a barrage of verbalize insights that in the end creates a vital, poetic image of the self" (pp. 140-141).

\section{Conclusion}

In recent Asian American scholarship, (auto)performance, as a genre came into prominence during Highways' multicultural phase, has now been a distant memory devoid of critical consciousness. In a naturalizing neoliberal multicultural context where racial subjects have been absorbed in what Melamed calls a "new form of whiteness", Asian American theater and performance are now experiencing a predicament of "racial contingency", a condition in which minoritarian subjects have been under-represented and rendered obsolete. To revive both the aura of theater and performance as well as critical consciousness for that matter, I proposed a necessity of revisiting to the heterolocus site of autoperformances by particularly looking at two significant solo Asian American artists (Denise Uyehara and Dan Kwong). Meanwhile, in the process of revisiting the site, I have also suggested a theoretical deployment of Taylor's "embodied memory" in rendering the ways in which body and memory, the two inextricable aspects, are played out effectively incorporation of what Taylor calls the "archival and epistemological repertoires" that records and transmits knowledge circulating between generations. Also, in the same course of reminiscing the long-forgotten site of autoperformances, we are thus reminded and enabled to consciously imagine this minoritarian "otherness" as a means to engage the very performative act of making relations between the (self) individual aesthetic and (social) cultural politics. In this way, by reimagining the otherness of autoperformance as an artistic dialect spoken onstage, multiculturalism could be "genuinely" practiced and possibly persisted.

\section{Declaration of Conflict of Interests}

The author(s) declared no potential conflicts of interest.

\section{Funding}

No funding has been received for the publication of this article. It is published free of any charge.

\section{Endnotes}

\footnotetext{
' Raz Schwartz and Germaine R Halegoua (2015) conceptualize "spatial self" as "a variety of instances (both online and offline) where individuals document, archive and display their experience and/or mobility with
} 
space and place in order to represent or perform aspects of their identity to others" (Schwartz \& Halegoua, 2015, p. 1644).

ii According to Meiling Cheng, Highways Performance Space in Santa Monica focuses on boundarybreaking, issue-oriented, and identity centered performances celebrated along with the discourse of multiculturalism in 1990s as the institution's artistic objectives. Highways has also been the vital center for performance art, which can be broadly define as an intermedia visual art form that uses theatrical elements in presentation. Highways has also served as a venue for experimental performance and dance, a gallery of exhibiting visual artworks (Cheng, 2001, pp. 432-433).

iii Drawing from Jean-François Lyotard's Postmodern Condition (1984), Christopher Lee (2012) elaborates that the post-modern does not chronologically follow the modern. Rather, it is a dissenting mode of representation that is always present even precedes, the modern. [...] post-modernism marks the modern from within (C. Lee, 2012, p. 8).

iv Citing from Franz Fanon in Black Skin, White Masks, Josephine Lee (1997) states that an individual's selfidentity is indelibly marked with what Fanon describes as a fixed "corporeal schema - the implicit knowledge...that each of us possesses of the position of his or her body in relation to other physical objects...the image each of us has of him- or herself as a body located somewhere in physical space... an image that each of us ordinarily constructs and needs repeatedly to reconstruct as he or she moves about the world" (J. Lee, 1997, p. 190).

"In The Show and the Gaze of Theatre: A European Perspective, Erika Fischer-Lichte (1997) describes "the human body never exists as pure nature, apart from history. From beginning of life, culture starts to shape, restructure, and regulate the body and its physical needs and functions. [...] As a result, each individual body participates not only in the natural order but also in the symbolic order of culture. The body, like any other cultural phenomenon, is historically determined" (Fischer-Lichte, 1997, p. 27).

vi In "Autobiography and the Making of America," Robert F. Sayre (1980) suggests that in black autobiography one constantly finds refutations of the white ideas of America, of both the white concepts of what characters and the white concepts of the black. To refer Frederick Douglas' intention of writing for a white audience in the hope of delivering the white man from political ignorance to knowledge, Sayre addresses such goal was to teach and persuade rather than to acquire white imitators; and thus emphasizes such experience in terms of an "American shame that had to be changed " rather an American ideal (Sayre, 1980, p. 166).

\section{References}

Bacalzo, D. (2004). Asian American I's: Race, Performane, and the Question of Autobiography [Doctor of Philosophy]. New York University.

Butler, J. (1988). Performative Acts and Gender Constitution: An Essay in Phenomenlogy and Feminist Theory. Theatre Journal, 40(4), 519-531.

Cheng, M. (2001). Highways, L.A.: Multiple Communities in a Heterolocus. Theatre Journal, 53(3), 429-454.

Fischer-Lichte, E. (1997). The Show and the Gaze of Theatre: A European Perspective Studies in Theatre History and Culture. University of Iowa Press.

Kong, I. C. (2020). Performing Refugee's Body and Memory: Poetics of Diaspora in Lê Thị Diễm Thúy's Autoperformance. Rupkatha Journal on Interdisciplinary Studies in Humanaties, 12(5). https://dx.doi.org/10.21659/rupkatha.v12n5.rioc1s21n1 
Kong, I. C. (2021). "A Sick Way of Thinking?": The Unorthodox Dramaturgy of Young Jean Lee's Identity Politics Theater. The Asian Journal of Literature, Culture, Performance, 1(2), 1-30.

Kurahashi, Y. (2002). Denise Uyehara. In M. X. Liu (Ed.), Asian American Playwrights: A bio-Bibliographical Critical Sourcebook (pp. 334-339). Greenwood Press.

Kwong, D. (1995, September 4). Counterpunch: Ethnic Images, Issues and "Asian Men." Los Angeles Times, $1-4$.

Kwong, D. (2004a). Correspondence of a Dangerous Enemy Alien (1995). In R. Vorlicky (Ed.), From Inner Worlds to Outer Space: The Multimedia Performances of Dan Kwong (pp. 109-139). The University of Michigan Press.

Kwong, D. (2004b). Monkhood in 3 Easy Lessons. In R. Vorlicky (Ed.), From Inner Worlds to Outer Space: The Multimedia of Dan Kwong (pp. 81-108). The University of Michigan Press.

Lee, C. (2012). The Semblance of Identity: Aesthetic Mediation in Asian American Literature. Stanford University Press.

Lee, E. K. (2003). Between the Personal and the Universal: Asian American Solo Performance from the 1970s to the 1990s. Journal of Asian American Studies, 6(3), 289-312.

Lee, J. (1997). Performing Asian America: Race and Ethnicity on the Contemporary Stage. Temple University Press.

Melamed, J. (2011). Represent and Destroy Rationalizing Violence in the New Racial Capitalism. University of Minnesota Press.

Muñoz, J. E. (2009). Cruising Utopia: The Then and There of Queer Futurity. New York University Press. Phelan, P. (1993). Unmarked: The Politics of Performance. Routledge.

Sayre, R. F. (1980). Autobiography and the Making of America. In J. Olney (Ed.), Autobiography: Essays Theoretical and Critical (pp. 146-168). Princeton University Press.

Schwartz, R., \& Halegoua, G. R. (2015). The Spatial Self: Location-based identity Performance on Social Media. New Media \& Society, 17(10), 1643-1660.

Sedgwick, E. K. (1993). Queer Performativity: Henry James's The Art of the Novel. GLO: A Journal of Lesbian \& Gay Studies, 1(1), 1-15.

Taylor, D. (2003). The Archive and the Repertoire: Performing Cultural Memory in the Americas. Duke University Press.

Uyehara, D. (2003). Maps of City and Body: Shedding Light on the Performances of Denise Uyehara. Kaya Press.

Vorlicky, R. (2004). Introduction: "Flying Alone in the Outer Spaces." In R. Vorlicky (Ed.), From Inner Worlds to Outer Spaces: The Multimedia Perforamances of Dan Kwong (pp. 1-10). The University of Michigan Press.

\section{Author's bio-note}

Io Chun Kong is an Assistant Professor in the Faculty of Humanities and Social Sciences, City University of Macau. His research interests include Asian American literary studies, theatre and performance studies, and cultural studies. 